\title{
Floral biology and visitors of Montrichardia arborescens (L.) Schott (Araceae) in Caxiuanã National Forest, Amazon Region, Brazil \\ Biologia floral e visitantes de Montrichardia arborescens (L.) Schott (Araceae) na Floresta Nacional de Caxiuanã, região amazônica, Brasil
}

\author{
Camila Nonato Junqueira!', Jennifer Muir"l, Alana Pindar"ll \\ Universidade Federal de Uberlândia. Uberlândia, Minas Gerais, Brasil \\ "University of Calgary. Calgary, Canadá \\ "IIYork University. Toronto, Canadá
}

\begin{abstract}
The genus Montrichardia is widely distributed across the Brazilian Amazon, however very little is known about its floral biology and floral visitors. This study, carried out over four days in September 2011 in the Caxiuanã National Forest aimed to investigate aspects of floral biology such as inflorescence growth, reproductive function, fruit size and principal visitors of Montrichardia arborescens in eastern Amazonia. It was estimated that the inflorescences monitored over the four day period were open for between 48-72 hours. Open inflorescences emitted more heat during morning visits compared to evening visits. Floral visitor numbers were dramatically lower than those reported in other studies. Out of the 75 individuals of Montrichardia arborescens observed, only seven received visitors. Results also showed no significant difference in pollen viability across measured spadix sections. Lastly, the number of carpels per fruit showed no significant effect on fruit size and shape.

Keywords: Araceae. Amazon Forest. Pollination. Pollinators. Floral development.

Resumo: O gênero Montrichardia é amplamente distribuído em toda a Amazônia brasileira, no entanto muito pouco se sabe sobre a biologia floral, e a literatura mostra dados contrastantes quanto aos visitantes florais. Este estudo foi realizado durante quatro dias em setembro de 2011, na Floresta Nacional de Caxiuanã, localizada na floresta amazônica brasileira, para investigar detalhadamente aspectos da biologia floral, como crescimento de inflorescência, função reprodutiva, tamanho do fruto, e quais os principais visitantes da Montrichardia arborescens no leste da Amazônia. Estimou-se que as inflorescências, monitoradas durante o período de quatro dias, ficaram abertas entre 48 e 72 horas. Inflorescências de Montrichardia arborescens emitem mais calor durante visitas no período da manhã, quando comparadas com visitas noturnas. O número de visitantes florais foi drasticamente inferior ao dos demais estudos. Dos 75 indivíduos de Montrichardia arborescens observados, apenas sete apresentaram visitantes florais. Os resultados também mostraram a ausência de diferença significativa na viabilidade do pólen ao longo de seções do espádice. Por último, o número de carpelos por fruto não mostrou efeito significativo sobre o tamanho e forma desses frutos.
\end{abstract}

Palavras-chave: Araceae. Floresta amazônica. Polinização. Polinizadores. Desenvolvimento floral.

JUNQUEIRA, C. N., J. MUIR \& A. PINDAR, 2014. Floral biology and visitors of Montrichardia arborescens (L.) Schott (Araceae) in Caxiuanã National Forest, Amazon Region, Brazil. Boletim do Museu Paraense Emílio Goeldi. Ciências Naturais 9(3): 503-508.

Autor para correspondência: Camila Nonato Junqueira. Universidade Federal de Uberlândia. Instituto de Biologia. Rua Ceará, s/n, bloco D - Umuarama. Uberlândia, MG, Brasil. CEP 38400-902 (camilanj@hotmail.com).

Recebido em 31/12/2013

Aprovado em 20/12/2014

Responsabilidade editorial: Alexander C. Lees

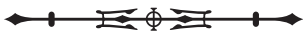




\section{INTRODUCTION}

The Araceae family is cosmopolitan and comprises more than 105 genera representing 3,300 species and reaches its highest diversity in the humid New World tropics - in Brazil there are 400 species in 34 genera (Mayo et al., 1997). Life forms range from submerged or free-floating aquatics to terrestrial and epiphytic or hemiepiphytic plants or climbers. Leaves range from simple and entire to compound and highly divided. The inflorescence is a spadix either bisexual or unisexual and subtended by a solitary spathe on a long or very short peduncle is a distinctive family feature (Boubes \& Barabé, 1997).

The genus Montrichardia is distributed in tropical America and contains two species, Montrichardia arborescens (L.) Schott and Montrichardia linifera (Arruda) Schott (Herrera et al., 2008). Both are evergreen herbs that grow in fresh-water habitats; they are widely distributed in the Amazonian floodplains and are found in many wetland ecosystems such as flooded forests and along river margins where they form dense stands (Macedo et al., 2005). They play an important role in the Amazonian ecosystem as their fruits form part of the diet of large native herbivores such as manatees and turtles (Portal et al., 2002).

Members of the Araceae are known to be entomophilous, pollinated principally by beetles and flies but also by bees and thrips (Williams \& Dressler, 1976; Rust, 1980). There is a strong family-wide correlation between floral features (inflorescence structure, rewards, attractants) and the type of pollinator (Barabé \& Lacroix, 2001). One well-known aspect of araceous inflorescences is the process of heating (Faegri \& van der Pijl, 1979; Mayo et al., 1997) which has been shown to provide an energy reward for pollinators by enabling the insect to reduce the energy cost of its activity (Dieringer et al., 1999; Seymour et al., 2003), and to increase volatilization of fragrant compounds, which are important in beetle attraction (Gottsberger, 1990).
Although Montrichardia sp. is widespread in Brazilian Amazonian forests, little is known about their floral biology and their pollination system and they are thought to be only pollinated by beetles (Gibernau et al., 2003). Thus, the objectives of this study were to investigate aspects of the floral biology such as reproductive function, fruit size and additionally to identify the principal visitors to Montrichardia arborescens in Amazonian forests.

\section{MATERIAL AND METHODS}

\section{STUDY SITE AND POPULATION}

Fieldwork was carried out in the Ferreira Penna Scientific Station, at the Caxiuanã National Forest in Melgaço, Pará, Brazil (010 42' 30" S; $51^{\circ}$ 31' 45” W) during September 2011. This forest is located in the north-central region of Pará State, Brazil, characterized by unflooded 'terra firme' (80\%), a small floodplain and several seasonally-flooded 'igapó' forests (20\%). The climate is tropical humid, with a short dry season from June to August (Oliveira et al., 2008). Plant studied were located both east and west of the field station with the majority of individuals located on the east side, where floodplain conditions were apparently comparable to the west side.

\section{INFLORESCENCE MORPHOLOGY, BIOLOGY AND VISITORS}

Inflorescence morphology was documented in the field and also in the laboratory with a stereomicroscope. Inflorescence width and depth of 16 individuals was recorded in the morning, from 08:00 to 10:00 and in the evening from 16:00 to $18: 00$, over a four day period. Enclosed inflorescences monitored were bagged at the beginning of the four days to ensure inflorescence morphology and biology could be investigated without interference from floral visitors. Inflorescence temperature was recorded at the same time to try and determine the flowering cycle. We used direct observation to study floral 
visitors of Montrichardia arborescens and all floral visitors observed in both morning and evening visits around the 16 monitored individuals were captured and identified.

\section{LABORATORY PROCEDURES}

To investigate pollen viability and stigma receptivity, 18 individuals were sampled across three age categories (buds: $n=6$; young flowers: $n=6$; old flowers: $n=6$ ). Stigma receptivity was determined using a peroxidase reaction following Dafni et al. (2005). Each spadix examined was divided into five zones (from top to bottom: L1, L2, L3, $\mathrm{L} 4$ and L5) to determine whether pollen viability changed according to position. Samples from each section were stained with basic fuschin following the methodology of Dafni et al. (2005) where viable pollen grains are said to hold the red stain and unviable grains remain unstained. All viable pollen grains per spadix zone were counted under 40x magnification.

Fruit examination was completed by weighing 11 inflorescences and counting the number of fruits in each inflorescence.

\section{STATISTICAL METHODS}

R. A. Fisher's exact test was undertaken to determine whether floral visitors preferred pollen-shedding inflorescences. Because inflorescence temperature were non-normally distributed, a Wilcoxon rank sum test was used to determine whether pollen-shedding inflorescences were warmer than younger inflorescences, as well as to determine whether time of day affected inflorescence temperature. A one-way ANOVA was used to determine whether there was any difference in pollen viability among the different spadix zones sampled. Linear regressions were used to determine whether the number of fruits present on a particular inflorescence would determine its shape (length: width ratio) and mass. Mean values are given with standard deviations, unless otherwise specified and statistical analysis was performed according to Zar (1999) using the statistical program Systat $10.2^{\circ}$ (SYSTAT, 2002).

\section{RESULTS}

\section{INFLORESCENCE MORPHOLOGY AND GROWTH}

Montrichardia arborescens individuals were observed to grow to 2-3 metres in height above the water level. The spathe was greenish-white. Yellow pistillate flowers were found on the lower $1 / 3$ of the spadix, while white/yellow staminate flowers on the upper $2 / 3$ of the spadix. $M$. arborescens inflorescences did not shed pollen at initial anthesis, but copious amounts of pollen were observed being emitted from staminate flowers in inflorescences that had been open for 24 hours or longer which indicates protogyny. Once pollen shedding began, the inflorescences remained open for 24-48 hours, until senescence when they turned brown and putrid.

When comparing the inflorescence temperature in inflorescences with pollen and without pollen, there was a trend toward inflorescences shedding pollen to be slightly cooler $\left(1.23 \pm 0.15^{\circ} \mathrm{C}\right)$ than inflorescences that had not yet reached the pollen-shedding stage $\left(1.40 \pm 0.15^{\circ} \mathrm{C}\right)$, however no significant difference in heat was detected $(W=844, p=0.3582$; see Figure 1). Open $M$. arborescens inflorescences were seen to emit more heat during

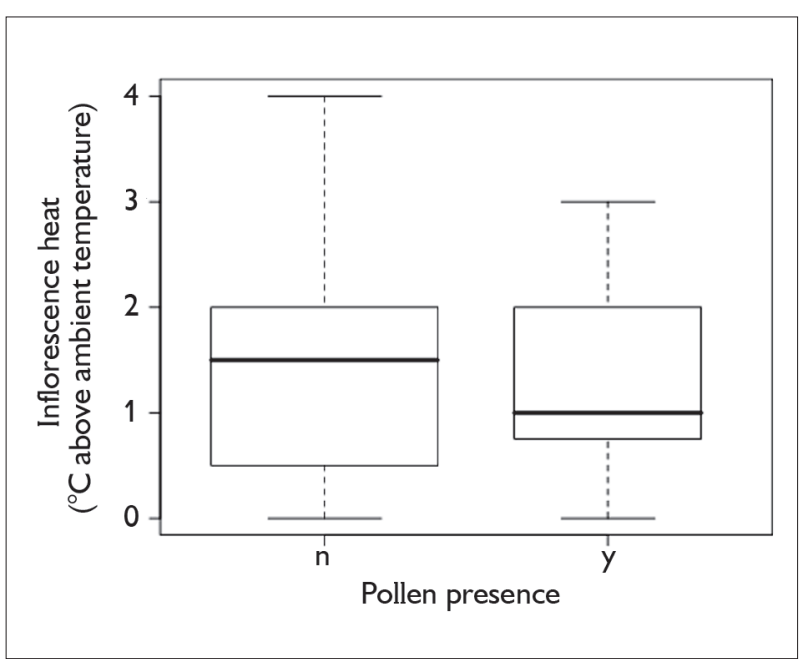

Figure 1. The effect of pollen presence on inflorescence heat of Montrichardia arborescens at Caxiuanã National Forest.

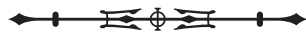


morning visits $\left(1.53 \pm 0.11^{\circ} \mathrm{C}\right)$ than during evening visits $\left(1.18 \pm 0.17^{\circ} \mathrm{C}\right)(\mathrm{W}=976, \mathrm{p}=0.04181$; see Figure 2$)$.

We found no significant difference in pollen viability between the five different sections of spadix sampled $\left(F_{4,25}=0.6804, p=0.612\right)$. Averaging among all spadix sections for each inflorescence, we saw a pollen viability of $57.2 \pm 4.53 \%$. Stigma receptivity was seen in $100 \%$ of the plants sampled; even in the immature bud-stage inflorescences and remained receptive until the pollen become available.

In terms of the M. arborescens fruits, we found no significant effect of the number of fruits present on either the shape of the inflorescence as defined by the length: width ratio $\left(R^{2}=-0.03, F_{1,28}=0.1473, p=0.704\right)$, or the mass of the inflorescence $\left(R^{2}=0.054, F_{1,28}=2.656, p=0.1143\right)$.

\section{INFLORESCENCE VISITORS}

A total of eight putative floral visitors were recorded on a total of seven of 75 M. arborescens inflorescences (9.3\%) subject to focal watches. The visitors included two grasshoppers (Orthoptera), three bees (Hymenoptera) and three beetles (Coleoptera). Visitors showed no preference for pollen shedding inflorescences over inflorescences without pollen ( $0.18 \%$ versus $0.07 \%$ respectively, $P=0.2553$, see Figure 3 ).

\section{DISCUSSION}

With their unisexual flowers, Montrichardia inflorescences are expected to have short flowering periods (two days) (Barabé \& Lacroix, 2001), although the flowering period longer (three-four days) as the inflorescence did not close at the end of the reproductive period (Gibernau et al., 2003). Our observations of $M$. arborescens were consistent with this, as we estimated that inflorescences were open for approximately $58 \pm 8$ hours.

In slight contrast to our results, Gibernau et al. (2003) found that spadix temperature of Montrichardia arborescens in French Guiana increased at the beginning of the night, remaining higher than the ambient temperature for approximately eight hours, returning to close to the

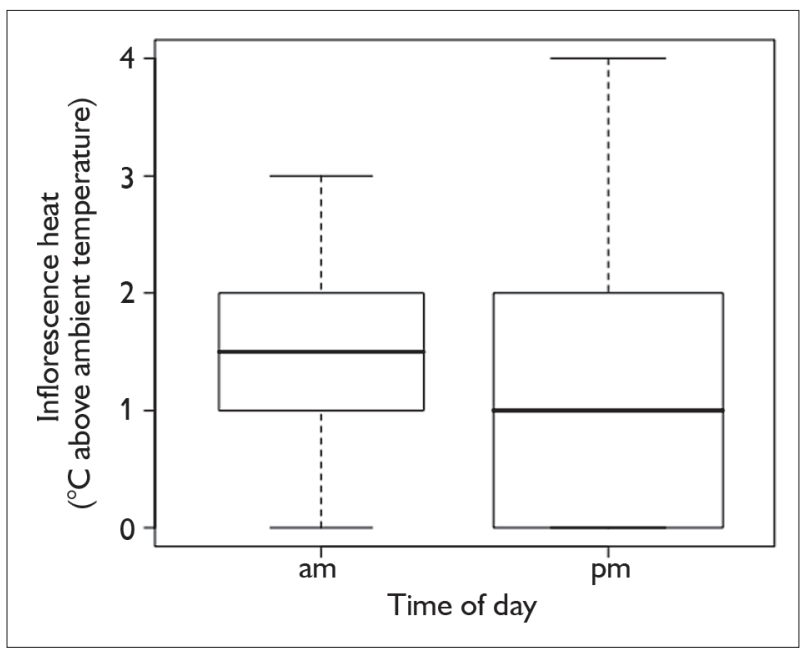

Figure 2. The effect of time of day (morning or evening) on the heat production of Montrichardia arborescens at Caxiuanã National Forest.

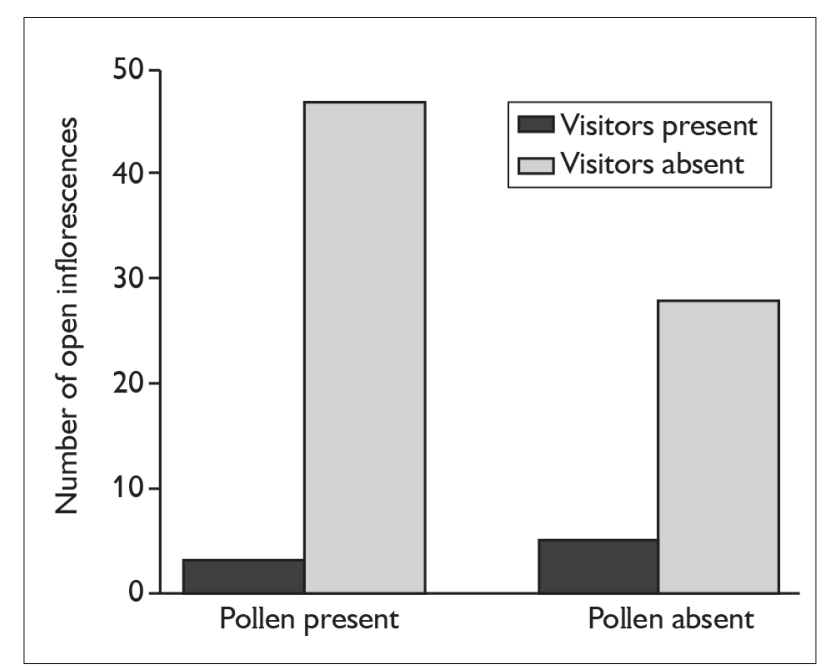

Figure 3. The effect of pollen presence on visitation of Montrichardia arborescens at Caxiuanã National Forest.

ambient temperature by midnight. They also observed that inflorescence temperature increased during both the first and second evenings following anthesis, and these temperature increases were much larger than those observed in the current study $\left(10-11^{\circ} \mathrm{C}\right.$ the first evening and $9-9.5^{\circ} \mathrm{C}$ the second evening, versus an average of $1.18^{\circ} \mathrm{C}$ for all open evening inflorescences). This difference between both studies could be due to contrasting weather conditions and the time of year during

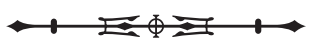


which both studies took place. Gibernau et al. (2003) conducted observations in July (dry season), where our study took place in September (wet season) with an average temperature of $24.2 \pm 0.8$.

The fact that inflorescences were (non-significantly) warmer when they were not shedding pollen suggests that pollinator attraction via warmth might be more important during the female stage of the protogynous flower, in which case heating may act to attract pollinators as observed in other Araceae specie (Gibernau \& Barabé, 2002). Alternatively, it is possible that the heat produced by the inflorescence is not related to pollination at all, but is simply a byproduct of the physiological processes of floral development and spathe opening (Gibernau et al., 2005).

We found that the period of pollen viability in Montrichardia was brief in comparison to other aroid genera, despite the large volume produced (Barabé \& Lacroix, 2001). We found that $57.2 \pm 4.53 \%$ of pollen (averaged across all regions of the spadix) was viable in the pollen shedding inflorescences sampled, while Barabé \& Lacroix (2001) saw that $70 \%$ of pollen was viable at initial anthesis, and that $50 \%$ and $0 \%$ of pollen was viable after 24 and 36 hours, respectively. Because we were not able to determine the age of each pollen-shedding inflorescence we sampled, we cannot compare our results at a fine scale, but the percentages of pollen viability are generally congruent.

All of the bees we found within inflorescences were shedding pollen in the secondary male phase. As M. arborescens is thought to be pollinated exclusively by beetles (Gibernau et al., 2003), we postulate that the bees were stealing pollen from the inflorescences and would not act as pollinators as they would not be attracted to the female phase of the protogynous inflorescence. Trigona bees were found in another study of $M$. arborescens reproduction, but these bees were seen only on buds and immature non-pollen-shedding inflorescences and were thought to be collecting nectar or water (Gibernau et al., 2003). Similarly, it is thought that the orthopteran inflorescence visitors may have been feeding upon the
Montrichardia tissue, but it is possible that they may have been transferring pollen between inflorescences, as some members of this order have recently been observed doing (Micheneau et al., 2009).

The very low number of inflorescences visited (only $0.93 \%$ of observed inflorescences) contrasts starkly with the observations of Gibernau et al. (2003), who saw dynastine beetles in 53 of 141 inflorescences (37.6\%). As beetle pollinators are thought to remain within the floral chamber of M. arborescens for 24-36 hours (Gibernau et al., 2003), it is unlikely that we would have missed these coleopteran visitors, as we observed inflorescences every 8-12 hours. It is uncertain how this lower floral visitation would affect $M$. arborescens populations, as we were unable to determine seed set in our population due to the length of the study. It is possible that very few inflorescence visitors are required for seed set in M. arborescens, or because the genus Montrichardia is known to be facultatively xenogamous (Gibernau et al., 2003; Barabé \& Lacroix, 2001); it is possible that many seeds are self pollinated. However, until further research is carried out on the $M$. arborescens populations we can only speculate on the repercussions of this low pollinator visitation on its reproductive success.

\section{ACKNOWLEDGEMENTS}

The authors are grateful to the instructors of the International Pollination Course for their always encouraging and helpful comments and suggestions. J. Muir and A. Pindar are also thankful for travel support provided by The Canadian Pollination Initiative - Natural Sciences and Engineering Research Council of Canada (CANPOLIN-NSERC).

\section{REFERENCES}

BARABÉ, D. \& C. LACROIX, 2001. The developmental floral morphology of Montrichardia arborescens (Araceae) revisited. Botanical Journal of the Linnean Society 135(4): 413-420.

BOUBES, C. \& D. BARABÉ, 1997. Flower and inflorescence development in Montrichardia arborescens (L.) Schott (Araceae). International Journal of Plant Sciences 158(4): 408-417. 
DAFNI, A., P. G. KEVAN \& B. C. HUSBAND (Eds.), 2005. Practical pollination biology: 1-590. Enviroquest, Harrisburg.

DIERINGER, G., R. L. CABRERA, M. LARA, L. LOYA \& P. REYESCASTILLO, 1999. Beetle pollination and floral thermogenicity in Magnolia tamaulipana (Magnoliaceae). International Journal of Plant Sciences 160(1): 64-71.

FAEGRI, K. \& L. VAN DER PIJL, 1979. The principles of pollination ecology: 1-244. Pergamon, Oxford.

GIBERNAU, M. \& D. BARABÉ, 2002. Pollination ecology of Philodendron squamiferum (Araceae). Canadian Journal of Botany 80(3): 316-320.

GIBERNAU, M., D. BARABÉ, D. LABAT, P. CERDAN \& A. DEJEAN, 2003. Reproductive biology of Montrichardia arborescens (Araceae) in French Guiana. Journal of Tropical Ecology 19(1): 103-107.

GIBERNAU, M., D. BARABÉ, M. MOISSON \& A. TROMBE, 2005. Physical constraints on temperature difference in some thermogenic aroid inflorescences. Annals of Botany 96(1): 117-125.

GOTTSBERGER, G., 1990. Pollination and flower evolution in neotropical Annonaceae. Annonaceae Newsletter 8: 35-36.

HERRERA, F. A., C. A. JARAMILLO, D. L. DILCHER, S. L. WING \& C. GÓMEZ-N., 2008. Fossil Araceae from a Paleocene neotropical rainforest in Colombia. American Journal of Botany 95(12): 1569-1583.

MACEDO, E. G., B. G. SANTOS FILHO, R. C. V. POTIGUARA \& D. S. B. SANTOS, 2005. Anatomia e arquitetura foliar de Montrichardia linifera (Arruda) Schott (Araceae) espécie da várzea amazônica. Boletim do Museu Paraense Emílio Goeldi, série Ciências Naturais 1(1): 19-43.
MAYO, S. J., J. BOGNER \& P. C. BOYCE, 1997. The Genera of Araceae: 1-370. Royal Botanic Gardens, Kew.

MICHENEAU, C., J. FOURNEL, B. H. WARREN, S. HUGEL, A. GAUVIN-BIALECKI, T. PAILLER, D. STRASBERG \& M. W. CHASE, 2009. Orthopera, a new order of pollinator. Annals of Botany 105(3): 355-364.

OLIVEIRA, L. L., R. FERREIRA DA COSTA, F. A. S. SOUSA, A. C. L. COSTA \& A. P. BRAGA, 2008. Precipitação efetiva e interceptação em Caxiuanã, na Amazônia Oriental. Acta Amazonica 38(4): 723-732.

PORTAL, R. R., M. A. S. LIMA, V. L. F. LUZ, Y. S. L. BATAUS \& I. J. REIS, 2002. Espécies vegetais utilizadas na alimentação de Podocnemis unifilis, Troschel 1948 (Reptilia, Testudinae, Pelomedusidae) na região do Pracuúba - Amapá - Brasil. Ciência Animal Brasileira 3(1): 11-19.

RUST, R. W., 1980. Pollen movement and reproduction in Arisaema triphyllum. Bulletin of the Torrey Botanical Club 107: 539-542.

SEYMOUR, R. S., M. GIBERNAU \& K. ITO, 2003. Thermogenesis and respiration of inflorescences of the dead horse arum Helicodiceros muscivorus, a pseudo-thermoregulatory aroid associated with fly pollination. Functional Ecology 17(6): 886-894.

SYSTAT, 2002. SYSTAT Software Inc.: version 10.2. San Jose.

WILLIAMS, N. H. \& R. L. DRESSLER, 1976. Euglossine pollination of Spathiphyllum (Araceae). Selbyana 1: 349-356.

ZAR, J. H., 1999. Biostatistical analysis: 1-663. Prentice Hall, Upper Saddle River. 